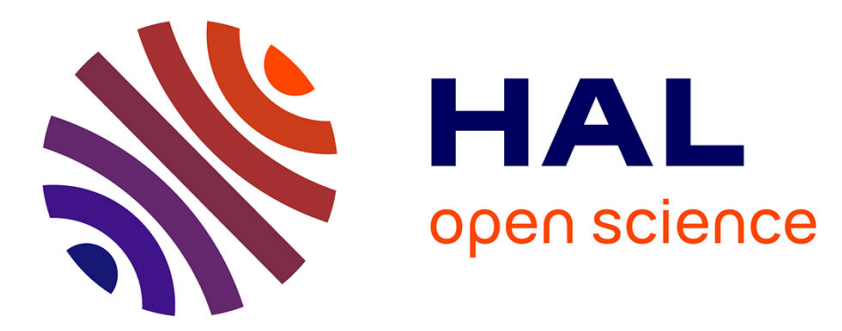

\title{
Lipid biomarkers in suspended particles from a subtropical estuary: Assessment of seasonal changes in sources and transport of organic matter Yunping Xu, Rudolf Jaffé
}

\section{- To cite this version:}

Yunping Xu, Rudolf Jaffé. Lipid biomarkers in suspended particles from a subtropical estuary: Assessment of seasonal changes in sources and transport of organic matter. Marine Environmental Research, 2007, 64 (5), pp.666. 10.1016/j.marenvres.2007.07.004 . hal-00562988

\section{HAL Id: hal-00562988 \\ https://hal.science/hal-00562988}

Submitted on 4 Feb 2011

HAL is a multi-disciplinary open access archive for the deposit and dissemination of scientific research documents, whether they are published or not. The documents may come from teaching and research institutions in France or abroad, or from public or private research centers.
L'archive ouverte pluridisciplinaire HAL, est destinée au dépôt et à la diffusion de documents scientifiques de niveau recherche, publiés ou non, émanant des établissements d'enseignement et de recherche français ou étrangers, des laboratoires publics ou privés. 


\section{Accepted Manuscript}

Lipid biomarkers in suspended particles from a subtropical estuary: Assessment of seasonal changes in sources and transport of organic matter

Yunping Xu, Rudolf Jaffé

PII:

S0141-1136(07)00090-6

DOI:

10.1016/j.marenvres.2007.07.004

Reference:

MERE 3135

To appear in:

Marine Environmental Research

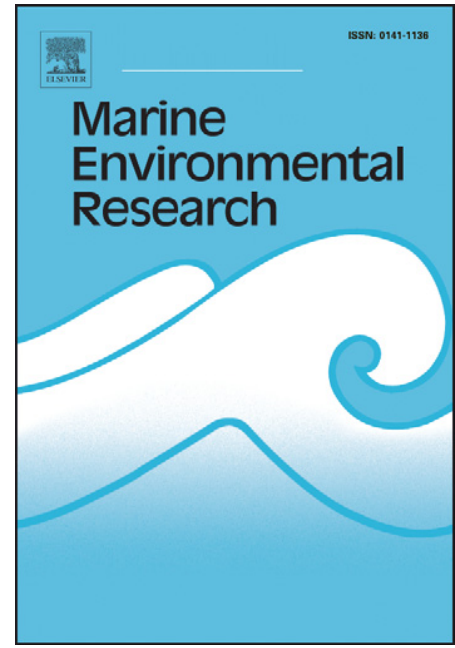

Received Date: $\quad 1$ June 2006

Revised Date: $\quad 2$ February 2007

Accepted Date: $\quad 8$ July 2007

Please cite this article as: Xu, Y., Jaffé, R., Lipid biomarkers in suspended particles from a subtropical estuary: Assessment of seasonal changes in sources and transport of organic matter, Marine Environmental Research(2007), doi: 10.1016/j.marenvres.2007.07.004

This is a PDF file of an unedited manuscript that has been accepted for publication. As a service to our customers we are providing this early version of the manuscript. The manuscript will undergo copyediting, typesetting, and review of the resulting proof before it is published in its final form. Please note that during the production process errors may be discovered which could affect the content, and all legal disclaimers that apply to the journal pertain. 
Lipid biomarkers in suspended particles from a subtropical estuary: 22 species and seagrasses during the dry season. Principal component analysis (PCA)

\section{Yunping $\mathrm{Xu}^{1}$ and Rudolf Jaffé*}

Environmental Geochemistry Group, Southeast Environmental Research Center and Department of Chemistry \& Biochemistry, Florida International University, Miami, 33199, USA

*Corresponding author: Tel: +1-305-348-3095; fax: +1-305-348-4096

E-mail address: jaffer@fiu.edu (R. Jaffé)

${ }^{1}$ Present address: Department of Physical \& Environmental Sciences, S433, University of Toronto, Toronto, ON M1C 1A4, Canada.

\section{Abstract}

Temporal and spatial variations in the composition of particulate organic matter (POM) from Florida Bay, USA were examined. The predominance of short chain homologues for $n$-alkanes, $n$-alcohols and $n$-fatty acids as well as relatively high abundance of $\mathrm{C}_{27}$ and $\mathrm{C}_{28}$ sterols suggested that an autochthonous/marine source of $\mathrm{OM}$ was dominant bay-wide. Several biomarker proxies such as $\operatorname{Paq}\left[\left(\mathrm{C}_{23}+\mathrm{C}_{25}\right) /\left(\mathrm{C}_{23}+\mathrm{C}_{25}+\mathrm{C}_{29}+\mathrm{C}_{31}\right) n\right.$-alkanes], short/long chain $n$-alkanes, $\left(\mathrm{C}_{29}+\mathrm{C}_{31}\right) n$-alkanes and taraxerol indicated a spatial shift in OM sources, where terrestrial OM rapidly decreased while seagrass and microbial OM markedly increased along a northeastern to southwestern transect. Regarding seasonal variations, POM collected during the dry season was enriched in terrestrial constituents relative to the wet season, likely as a result of reduced primary productivity of planktonic

23 classified the sample set into sub-groups based on PC1 which seemed to be spatially 
24 controlled by OM origin (terrestrial-mangrove vs. marine-planktonic/seagrass). The PC2

25 seemed to be more seasonally controlled suggesting that hydrological fluctuations and

26 seasonal primary productivity are the drivers controlling the POM composition in Florida

27 Bay.

28 Key words: suspended particulate organic matter, Florida Bay, lipid biomarkers, seagrass,

29 mangroves

\section{1. Introduction}

32 Relative to open oceans, coastal areas are highly vulnerable to environmental

33 change due to their small size and location close to urban areas (Canuel, Cloern, Ringelberg,

34 Guckert, \& Rau, 1995). Coastal areas serve as sites of organic material exchange between

35 land and oceans and are also active zones where $\mathrm{OM}$ is produced by higher plants, 36 phytoplankton, benthic algae and bacteria (e.g. Jaffé, Mead, Hernandez, Peralba, \& 37 DiGuida, 2001; Jaffé, Boyer, Lu, Maie, Yang, \& Scully et al., 2004; McCallister, Bauer, 38 Ducklow, \& Canuel, 2006). Additionally, aquatic vegetation is often abundant in coastal 39 wetlands and estuarine areas and also serves as a significant source of OM (e.g. Campbell, 40 \& Miller, 2002;Jaffé et al., 2001; Paula, Fidalgo Ecosta, Martins, \& Gove, 2001). This is 41 the case of Florida Bay, where dense seagrass prairies dominate the benthic communities 42 (Zieman, Fourqurean, \& Iverson, 1989). The strength of each OM source can vary spatially 43 as well as temporally on seasonal to tidal cycle time scales. Various methods have been employed to characterize OM in aquatic environments.

45 Among them, lipid tracers or biomarkers are particularly useful because they can reveal 46 valuable information on OM sources at the molecular level (Meyers, 2003). Previous 


\section{ACCEPTED MANUSCRIPT}

47 studies have successfully used this approach to assess sedimentary OM sources in coastal

48 areas, estuaries, rivers and lakes (e.g. Bianchi, Mitra, \& McKee, 2002; Jaffé et al., 2001;

49 Mead, Xu, Chong, \& Jaffé, 2005; Prartono, \& Wolff, 1998; Volkman, Rohjans, Rullkotter,

50 Scholz-Bottcher, \& Liebezeit, 2000). However, OM preserved in sediments may not always

51 accurately reflect original inputs. In fact over $90 \%$ of organic material produced by the

52 source organisms is degraded or consumed before reaching the sediments (Eadie, Chambers,

53 Gardner, \& Bell, 1984), and the preferential degradation of more labile plankton derived

54 OM enhanced the apparent importance of terrestrial contributions which contain more

55 resistant constituents (Meyers, 2003). In aquatic environments, suspended particles serve as

56 an important vehicle in the transfer of OM from sources to sediments. Thus through the

57 comparison of OM composition between sediments and suspended particles, early

58 degradation processes of OM can be assessed (Canuel et al., 1995; Jaffé, Cabrera, Hajje, \&

59 Carvajal-Chitty, 1996; Saliot, Mejanelle, Scribe, Fillaux, Pepe, \& Jabaud et al. , 2001),

60 allowing for a better source strength interpretation of sedimentary OM.

61 While lipids in sediments and soils from south Florida estuaries have been reported

62 (e.g. Hernandez, Mead, Peralba, \& Jaffé, 2001; Jaffé et al., 2001; Mead et al., 2005; Neto,

63 Mead, Louda, \& Jaffé, 2006; Xu, Jaffé, Wachnicka, \& Gaiser, 2006a; Xu, Mead, \& Jaffé,

64 2006b), little is known about the sources and transport of particulate organic matter (POM).

65 Here, we assess the spatial and temporal variation in the composition and origin of POM in

66 Florida Bay through the measurement of several classes of lipid biomarkers such as

67 aliphatic hydrocarbons, sterols, aliphatic alcohols, fatty acids, highly branched isoprenoids

68 (HBIs) and terrestrially derived triterpenoids from the Florida Bay estuary, South Florida. 
87 Florida Coastal Everglades Long Term Ecological Research project's (FCE-LTER;

88 http://fcelter.fiu.edu/) Taylor Slough/Pan Handle sampling transect (TS/Ph 7, 8, 9, 10 and

89 11; Fig. 1). The samples will subsequently be referred to as W1 and W2 for the wet season

90 (October 2003 and 2004, respectively) or D1 and D2 for the dry season (March 2004 and

91 April 2005, respectively) followed by their corresponding site number (7, 8, 9, 10 and 11).

92 For example, W1-7 indicates a sample from $\mathrm{TS} / \mathrm{Ph} 7$ during the wet season of 2003. For 
93 each sample, 50 liters of waters were collected at $20 \mathrm{~cm}$ depth and kept in clean

94 polycarbonate bottles (Nalgene) until transport to the laboratory (within 8 hours of

95 collection). Samples were kept on ice and immediately vacuum filtered through pre-

96 combusted glass-fiber filters with $0.7 \mu \mathrm{m}$ nominal pore size $(\mathrm{GF} / \mathrm{F})$. The filters with

97 particulate material were freeze-dried at $-40^{\circ} \mathrm{C}$ under the vacuum condition $\left(<100 \times 10^{-3}\right.$

$98 \mathrm{mBar})$. After that, dried samples were kept at $-20^{\circ} \mathrm{C}$ until analysis.

99

100 2.3. Chemical analysis

101 The analytical procedure used in this study has been described by Jaffé et al. (2001).

102 Briefly, dried filters were Soxhlet extracted with pure methylene chloride (Optima, Fisher,

103 USA) for 24 hours. Activated copper was added to remove any elemental sulfur from the

104 organic extracts. Total extractable organics were saponified with $1.0 \mathrm{~N} \mathrm{KOH}$ and separated

105 into neutral and acid fractions. The neutral fraction was further separated by silica gel

106 adsorption chromatography. Known amounts of squalane and per D phenanthrene were

107 added as internal standards for aliphatic hydrocarbons and other fractions, respectively. The

$108 \%$ error of the compound quantifications was of the order of 5-8\%. Prior to analysis by GC-

109 MS, the acid fraction was derivatized with freshly distilled diazomethane and the aliphatic

110 alcohol and sterol fractions were derivatized with bis(trimethylsilyl)trifluoroacetamide

111 (BSTFA) after addition of $10 \mu 1$ pyridine.

112 A HP 5973 GC-MS system was used for the analysis and operated in electron

113 impact (EI) ionization mode at 70eV. The capillary column was a DB5 MS (30m, $0.25 \mathrm{~mm}$

114 i.d., $0.25 \mu \mathrm{m})$. The $\mathrm{GC}$ oven was programmed from 60 to $180^{\circ} \mathrm{C}$ at a rate of $6.0^{\circ} \mathrm{C} / \mathrm{min}$ after

$1151 \mathrm{~min}$ at the initial temperature; then increased to $315^{\circ} \mathrm{C}$ at a rate of $3^{\circ} \mathrm{C} / \mathrm{min}$ and kept at the 
116 maximum temperature for $15 \mathrm{~min}$. The identification of individual compounds was

117 performed by comparison of chromatographic retention time and mass spectra of authentic

118 standards and those previously reported in the literature.

\section{Results and discussion}

Several lipid compound classes such as $n$-alkanes, sterols, fatty acids and aliphatic

$122 n$-alcohols as well as highly branched isoprenoids (HBIs) and pentacyclic triterpenoids

123 were examined. All concentrations are expressed in ng per liter (ng/L).

125 3.1. Aliphatic hydrocarbons

126 A homologous series of $n$-alkanes ranging from $\mathrm{C}_{15}$ to $\mathrm{C}_{33}$ was observed and 127 displayed a strong odd-over-even carbon number predominance, reflected by their high 128 carbon preference index values (CPI; Fig. 2A and Table 1). Their total concentrations 129 varied from 37 to $349 \mathrm{ng} / \mathrm{L}$ (Table 1). The $\mathrm{C}_{15}$ and $\mathrm{C}_{17}$ homologues dominated the $n$-alkane 130 distribution accounting for up to $81 \%$ of the total $n$-alkanes, while the $\mathrm{C}_{29}$ and $\mathrm{C}_{31} n$-alkanes,

131 indicative of terrestrially derived OM, were only minor components (0 24\%). This 132 distribution suggested a primary influence of phytoplankton (Cranwell, Eglinton, \& 133 Robinson, 1987). All POM samples except D2-7 featured an average carbon-chain length 134 (ACL) of $n$-alkanes from 16.4 to 21.8, also reflecting strong microbial (planktonic) OM 135 inputs.

136 Whereas surface sediments have a seagrass-derived lipid signature (Table 2; Xu et

137 al., 2006b), POM was characterized by predominant phytoplankton-derived compounds.

138 This difference may reflect (1) the preferential degradation of short-chain (microbial and 
139 algal) $n$-alkanes relative to mid- (seagrasses) and long-chain (mangrove) counterparts

140 during early diagenesis of POM and surface sediment OM; and (2) an unimportant

141 contribution of seagrass- and mangrove-derived in resuspended OM relative to planktonic

142 POM in the water column.

143 Along the NE to SW transect, the percentage of $\left(\mathrm{C}_{29}+\mathrm{C}_{31}\right) n$-alkanes gradually

144 decreased from 1.5 to $0.3 \%, 13$ to $2.7 \%, 8.2$ to $0 \%$ and 24 to $2.7 \%$ for the W1, D1, W2 and

145 D2 series, respectively, suggesting a consistent decrease in the source strength of

146 terrestrially-derived OM toward offshore areas. The ratio of long/short $\left(>\mathrm{C}_{20} / \leq \mathrm{C}_{20}\right) n$ -

147 alkanes, an indicator of terrestrial vs. marine OM, generally decreased from the NE (site 7

148 and 8) to the central section (site 9) and then increased to the SW bay (site 10, 11), likely as

149 a result of a strong influence of seagrasses in off-shore areas, which are characterized by

150 high amounts of $\mathrm{C}_{23}$ and $\mathrm{C}_{25} n$-alkanes (Jaffé et al., 2001; Mead et al., 2005). This data is

151 consistent with previous reports that planktonic primary productivity is the highest in the

152 central section of the Bay (Philips, Lynch, \& Badylak, 1995).

153 The $n$-alkane based $P a q$ value, defined as $\left(\mathrm{C}_{23}+\mathrm{C}_{25}\right) /\left(\mathrm{C}_{23}+\mathrm{C}_{25}+\mathrm{C}_{29}+\mathrm{C}_{31}\right) n$-alkanes,

154 was proposed as a means to distinguish between non-emergent and emergent plant derived

155 OM (Ficken, Li, Swain, \& Eglinton, 2000). Mead et al. (2005) reported Paq values for

156 seagrasses, Rhizophora mangle and Cladium sp. (sawgrass) as 0.90-1.00, 0.24 and 0.10,

157 respectively. This distinct difference makes the $P a q$ a good proxy to estimate seagrass

158 inputs in Florida Bay. The Paq value of POM markedly increased from site 7 (as low as

1590.30 ) to site 11 (up to 1.0) (Fig. 3), reflecting spatial variations in the strength of seagrass

160 vs. terrestrial (e.g. mangrove) OM. It should be noted that phytoplankton contributions are

161 not reflected in the Paq proxy. 
The POM samples from the dry season (D1 and D2) were enriched in terrestrial

163 components relative to those from the wet season (W1 and $\mathrm{W} 2$ ), as reflected by several $n$ -

164 alkane based proxies. The percentage of high molecular weight $n$-alkanes $\left(\mathrm{C}_{29}+\mathrm{C}_{31}\right)$ ranged

165 from 3 to $24 \%$ during the dry season $v s$. 0 to $8 \%$ during the wet season. The sample D2-7

166 showed the lowest Paq value (0.3), the highest ACL value (25.0) and the most abundant

167 long-chain $n$-alkanes (24\%). The terrestrial "background" signal is apparently suppressed

168 by the higher autochthonous primary production in the summer months in Florida Bay (wet

169 season).

170 Several $\mathrm{C}_{20}, \mathrm{C}_{25}$ and $\mathrm{C}_{30}$ highly branched isoprenoids (HBIs) were detected in the

171 aliphatic hydrocarbon fractions (Fig. 2A). The $\mathrm{C}_{20} \mathrm{HBI}$ compounds consisted of the

172 saturated alkane namely 2, 6, 10-trimethyl-7-(3-methylbutyl)dodecane $\left(\mathrm{C}_{20: 0}\right.$; Retention

173 index; $\mathrm{RI}_{\mathrm{DB} 5}$ 1693) and its corresponding monounsaturated alkene (C20:1 $\mathrm{DB}$ 1685) (Jaffé et

174 al., 2001). The $\mathrm{C}_{20} \mathrm{HBI}$ was present at concentrations as high as $433 \mathrm{ng} / \mathrm{L}$ while that of the

$175 \mathrm{C}_{25}$ HBIs reached 100ng/L. The $\mathrm{C}_{30}$ HBIs, however, were only detectable in the D2 series

176 at a concentration below 10ng/L. Cyanobacteria have been suggested as a potential source

177 for the $\mathrm{C}_{20}$ HBIs, but direct evidence for this is still lacking (Jaffé et al., 2001; Kenig,

178 Sinninghe Damsté, Kock-van Dalen, Rijpstra, Huc, \& de Leeuw, 1995). In contrast, the

179 biosynthesis of $\mathrm{C}_{25}$ HBIs by some diatoms has been firmly established (Sinninghe Damsté,

180 Muyzer, Abbas, Rampen, Massé, \& Allard et al. , 2004; Volkman, Barrett, \& Dunstan,

181 1994). The $\mathrm{C}_{30}$ HBIs are also biosynthesized by some marine diatoms (Sinninghe Damsté et

182 al., 2004; Volkman et al., 1994).

183 Regarding the spatial distribution, $\mathrm{C}_{20}$ HBIs were generally more abundant at the

$184 \mathrm{NE}$ and central Bay relative to the SW Bay especially at TS/Ph 11. This distribution reflects 


\section{ACCEPTED MANUSCRIPT}

185 the mixed contribution of cyanobacterial mats and periphyton mats which are abundant in 186 the NE and central Bay and in the freshwater Everglades, respectively (Jaffé et al., 2001).

187 The $\mathrm{C}_{25}$ HBIs were most abundant in the central Bay POM, as in the surface sediments $(\mathrm{Xu}$

188 et al., 2006b), reflecting autochthonous marine diatom inputs, while the absence of $\mathrm{C}_{30}$ 189 HBIs in most POM samples may be a reflection of weak source strengths or fast 190 degradation of those polyunsaturated compounds.

$192 \quad 3.2$ Sterols

193 The concentrations of $\mathrm{C}_{26}-\mathrm{C}_{30}$ sterols ranged from 91 to 3040ng/L (Fig. 2D and

194 Table 1). Among them, the principal compounds were cholest-5-en-3 $\beta$-ol $\left(\mathrm{C}_{27} \Delta^{5} ; 10-48 \%\right)$,

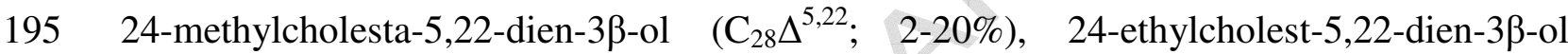
$196\left(\mathrm{C}_{29} \Delta^{5,22} ; 2-72 \%\right)$ and 24-ethylcholest-5-en-3 $\beta$-ol $\left(\mathrm{C}_{29} \Delta^{5} ; 4-16 \%\right)$. Figure 4 shows the 197 relative abundance of $\mathrm{C}_{26}-\mathrm{C}_{30}$ sterols in the POM samples. $\mathrm{C}_{27}, \mathrm{C}_{28}$ and $\mathrm{C}_{29}$ sterols were 198 abundant, but the $\mathrm{C}_{26}$ and $\mathrm{C}_{30}$ compounds were minor or undetectable. The only $\mathrm{C}_{26}$ sterol, 199 24-norcholesta-5,22E-dien-3 $\beta$-ol $\left(\mathrm{C}_{26} \Delta^{5,22}\right)$ accounted for $<3 \%$ of total sterols. The $\mathrm{C}_{27}$ 200 sterols were dominated by $\mathrm{C}_{27} \Delta^{5}$ (10 to 48\%) followed by cholesta-5,22-dien-3ß-ol

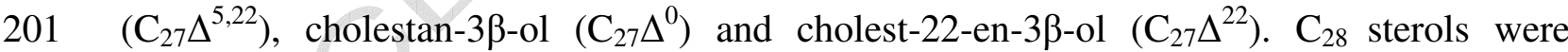
202 composed of $\mathrm{C}_{28} \Delta^{5,22}$, 24-methylcholesta-22E-en-3 $\beta$-ol $\left(\mathrm{C}_{28} \Delta^{22}\right)$, 24-methylcholesta-

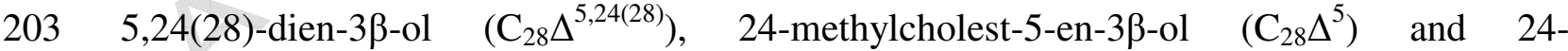
204 methylcholestan-3 $\beta$-ol $\left(\mathrm{C}_{28} \Delta^{0}\right)$. Among them, $\mathrm{C}_{28} \Delta^{5}(2-8 \%)$ and $\mathrm{C}_{28} \Delta^{5,22}(2-20 \%)$ were the 205 most abundant in most POM samples except for W1-11 which had $\mathrm{C}_{28} \Delta^{5,24(28)}$ at a 206 concentration of $445 \mathrm{ng} / \mathrm{L}$. The percentages of $\mathrm{C}_{29}$ sterols were relatively constant and 207 accounted for $\sim 25 \%$ of the POM samples, except for the $\mathrm{W} 1$ series where this value 
208

209

210

211

212

213

214

215

216

217

218

219

220

221

222

223

224

225

226

227

228

229

230

markedly decreased from site 7 to site 11 (Fig. 4). Several $\mathrm{C}_{30}$ sterols such as $4 \alpha$-methyl24-ethyl-5 $\alpha(H)$-cholest-22(E)-en-3 $\beta$-ol $\quad\left(\mathrm{C}_{30} \Delta^{22}\right), 4 \alpha, 23,24$-trimethyl-5 $\alpha(H)$-cholest-22(E)-

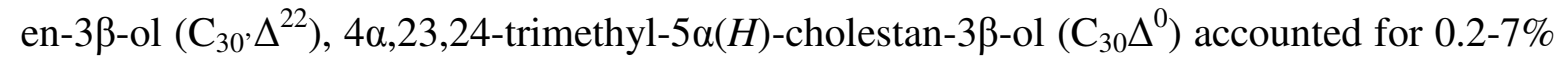
of the total sterols.

While the low abundance of $\mathrm{C}_{26}$ sterols may reflect minimal inputs of $\mathrm{OM}$ from marine animals (de Leeuw, Rijpstra, Schenck, \& Volkman, 1983; Jiang, O'Leary, Volkman, Zhang, Jia, \& Yu et al., 1994), the relatively high percentages of $\mathrm{C}_{27} \Delta^{5}(10-48 \%)$ suggested an important contribution from zooplankton-derived OM, although an origin from other organisms is possible (Volkman, 1986). $\mathrm{C}_{28}$ sterols were relatively abundant in most POM samples, indicating a significant input from phytoplankton especially diatoms (Volkman, 1986), although these sterols have also been found to be abundant in seagrasses (Jaffé et al., 2001).

$\mathrm{C}_{29}$ sterols have been widely used as biomarkers of terrestrial OM (Huang, \& Meinschein, 1976; 1978), but they are also biosynthesized by some microalage (Volkman, 1986; Volkman, Barrett, Blackburn, Mansour, Sikes, \& Gelin, 1998). In Florida Bay, $\mathrm{C}_{29} \Delta^{5}$ in seagrasses accounts for $\sim 75 \%$ of total sterols (Jaffé et al., 2001). Therefore, the high abundance of $\mathrm{C}_{29}$ sterols does not necessarily reflect a large terrestrially-derived $\mathrm{OM}$ input in Florida Bay, which is corroborated by the dominance of short-chain $n$-alkanes and the high Paq values $(>0.81)$. The $\mathrm{C}_{28} \Delta^{5}: \mathrm{C}_{29} \Delta^{5,}{ }^{22}: \mathrm{C}_{29} \Delta^{5}$ ratio of POM fell in the range of 1:0.76:1.24 to $1: 9.93: 0.90$, while higher plants have this value in the order of $1: 1.4: 4.0$ to 1:1.6:6.6 (Gogou, \& Stephanou, 2004; Volkman, 1986). A significantly enhanced abundance of $\mathrm{C}_{28} \Delta^{5}$ and $\mathrm{C}_{29} \Delta^{5,22}$ relative to $\mathrm{C}_{29} \Delta^{5}$ in POM suggests an important $\mathrm{OM}$ input from marine algae. The relative abundance of the $\mathrm{C}_{27}$ vs. $\mathrm{C}_{29}$ sterols did not show 


\section{ACCEPTED MANUSCRIPT}

231 pronounced variations along the NE to SW transect for D1, W2 and D2 series (1 to 3),

232 again suggesting seagrass as an important POM source. As a biomarker for dinoflagellates

233 (de Leeuw et al., 1983), $\mathrm{C}_{30} \Delta^{22}$ (dinosterol) remained at low abundance in the POM,

234 suggesting only minor contributions from these organisms. The presence of only minor

235 amounts of stanols in the POM samples suggests that this OM is fairly fresh and has not

236 undergone significant degradation (Jaffé et al., 1996; Wakeham, \& Lee, 1989).

$238 \quad 3.3$ Fatty acids

239 The concentration of fatty acids was as high as $2580 \mathrm{ng} / \mathrm{L}$ (Table 1 ). The $n$-fatty acid

240 homologues displayed a strong even-over-odd carbon predominance (Fig. 2B). Short-chain

241 fatty acids (SCFAs; $\leq \mathrm{C}_{20}$ ) are mainly derived from planktonic and microbial organisms,

242 while long-chain fatty acids (LCFAs; $>\mathrm{C}_{20}$ ) are produced by higher plants including

243 seagrasses (Jaffé et al., 2001). Therefore, the high SCFAs/LCFAs values observed for POM

244 (up to 47) suggest a primary marine planktonic influence, in agreement with the data from

$245 n$-alkanes. However, seagrasses, commonly covered by epiphytic organisms, cannot be

246 excluded as an important source as they have a strong predominance at $\mathrm{C}_{16}$ followed by $\mathrm{C}_{24}$

247 in their fatty acids distributions (Jaffé et al., 2001). The long chain fatty acids observed here

248 are most likely derived from mixed inputs of seagrasses and mangroves. Fatty acid

249 homologues maximized at $n-\mathrm{C}_{14}(300 \mathrm{ng} / \mathrm{l})$ for $\mathrm{W} 1-11$, a distribution typical of 250 phytoplankton.

251 The relative abundance of monounsaturated fatty acids (MUFAs) varied from $7 \%$ to

252 27\%, indicating an important microbial contribution to the POM. Compared to the 253 abundance of polyunsaturated fatty acids (PUFAs) in surface sediments (0.7-13\%; Table 2; 


\section{ACCEPTED MANUSCRIPT}

$254 \mathrm{Xu}$ et al., 2006b), the POM samples showed markedly elevated concentrations of these 255 constituents (7-57\%), which can be attributed to the preferential degradation of MUFAs 256 and PUFAs relative to their saturated counterparts during early diagenesis (Meyers, 2003).

257 The proportion of branched fatty acids in the POM (0.6-4\%) was significantly lower than 258 that in surface sediments (5-15\%; Table 2; Xu et al., 2006b), reflecting a more active 259 bacterial reworking at the sediment-water interface (Gogou, \& Stephanou, 2004) and a 260 reduced contribution of these compounds from sediment resuspension. Branched fatty acids, 261 principally iso- and anteiso- $\mathrm{C}_{15}$ and $\mathrm{C}_{17}$, are found to be abundant in bacteria (Budge, \& 262 Parrish, 1998). Wakeham and Beier (1991) proposed a bacterial indicator value of $6 \%$ to be

263 rather low and not indicative of a large contribution of fatty acids from bacteria.

264 Some fatty acid based proxies can reflect a shift in phytoplankton taxonomic classes

265 such as diatoms and dinoflagellates. The ratios of $\mathrm{C}_{16: 1} / \mathrm{C}_{16: 0}, \Sigma \mathrm{C}_{16} / \Sigma \mathrm{C}_{18}$ and $\mathrm{C}_{20: 5} / \mathrm{C}_{22: 6}$ have 266 been proposed as indicators of diatoms (Budge, \& Parrish, 1998; Ramos, Parrish, Quibuyen, $267 \&$ Abrajano, 2003). For the Florida Bay POM, the ratio of $\mathrm{C}_{16: 1} / \mathrm{C}_{16: 0}$ remained below 1.0 268 while the $\Sigma \mathrm{C}_{16} / \Sigma \mathrm{C}_{18}$ was generally higher than 1.0 and had the maximum value of 3.2 269 (Table 1). This apparent disagreement between the two diatom indicators is most likely 270 attributed to an interference of seagrass derived OM (possibly from epiphytes) in which the $271 \quad \mathrm{C}_{16: 0}$ fatty acid is dominant (Jaffé et al., 2001). Therefore, such proxies involve non-source 272 specific biomarkers, and hence their applicability can be limited. The ratio of $\mathrm{C}_{20: 5} / \mathrm{C}_{22: 6}$ was 273 as high as 12, indicating an important contribution from diatoms. Seasonally, the percentages of (MUFAs+PUFAs) in the POM remained at relatively

275 constant, high levels, suggesting consistently important contributions of phytoplankton 
276 derived OM. The fatty acids also showed higher percentages of long-chain homologues

277 during the dry season, as did the $n$-alkanes.

3.4 -Alkanols

The $n$-alkanol distribution exhibited a strong even over odd carbon number

281 predominance with concentrations ranging from 16 to 1220ng/L (Table 1 and Fig. 2C).

282 Terrestrial plants produce long chain $n$-alkanols from $C_{22}$ to $C_{32}$ (Sever, \& Parker, 1969),

283 while short chain $\left(\leq \mathrm{C}_{20}\right) n$-alkanols are characteristic of microbial OM inputs (Robinson,

284 Cranwell, Finlay, \& Eglinton, 1984). The $n$-alkanol distributions in most POM samples

285 showed maxima at short chain homologues $\left(\mathrm{C}_{12}-\mathrm{C}_{18}\right)$, again consistent with a predominant

286 algal and microbial OM origin. However, a few of the dry season samples (i.e., D1-7, D1-8

287 and D2-7) had significant levels of $\mathrm{C}_{28}$ or $\mathrm{C}_{30} n$-alkanols (Table 1), suggesting important

288 higher plant inputs (Jaffé et al., 2001). This supports the interpretation of the $n$-alkane and 289 fatty acid distributions as having higher relative contributions from terrestrial-higher plant

290 OM in the dry season. The ratio of long chain/short chain $n$-alkanols markedly decreased

291 (Table 1), further confirming a decreasing trend of terrestrial influence toward offshore. In

292 regards to seasonality, the dry season samples had higher values of long/short chain $n$ -

293 alkanols (0.2-10) relative to the wet season samples (0.0-1.4), suggesting more terrestrial

294 OM components for the former, while wet season OM sources seem controlled by 295 increased planktonic primary productivity.

297 3.5 Higher plant derived pentacyclic triterpenoids 
Pentacyclic triterpenoids such as taraxerol, $\beta$-amyrin and lupeol are widely found in

299 higher plants, especially in trees, but rarely in other organisms. Hence they are often used

300 as biomarkers of terrestrial inputs (Brassell, Eglinton, \& Maxwell, 1983; ten Haven, \&

301 Rullkotter, 1988; Versteegh, Schefuß, Dupont, Marret, Sinninghe Damsté, \& Jansen, 2004).

302 Previous studies have reported taraxerol concentration of up to $1.4 \mathrm{mg} / \mathrm{g}$ in mangrove

303 leaves (Versteegh et al., 2004) but it is absent in the other two main higher plant biomass

304 components of the Everglades ecosystem, namely seagrass and sawgrass (Xu et al., 2006b).

305 Several pentacyclic triterpenoids such as taraxerol, $\beta$-amyrin, germanicol and lupeol were

306 detected in the POM. Overall, their concentrations rapidly decreased from site 7 to 11

307 (Table 1), suggesting reduced transport from the NE mangrove fringe to the Bay and/or the

308 sparse distribution of mangrove tree islands in SW Florida Bay. The abundance of these

309 triterpenoids was found to be higher during the dry season (D1 and D2) relative to the wet

310 season (W1 and W2). For example, taraxerol, a specific biomarker of mangroves

311 (Versteegh et al., 2004), was as high as 1210ng/L for the D1 series and 109ng/L for the D2

312 series, but only 19ng/L for the W1 series and 102ng/L for the W2 (Table 1). These results

313 are in agreement with data on source variations for dissolved organic matter (DOM) in

314 Florida Bay (Maie, Boyer, Yang, \& Jaffé, 2006).

3163.6 Principal components analysis (PCA)

317 PCA is a multivariate statistical technique, useful in extracting information from 318 complex organic geochemical data (e.g. Hernandez et al., 2001; Mead et al., 2005; Mudge, 319 East, Bebianno, \& Barreira, 1998). Figure 5 shows the PCA score plot for POM in Florida 320 Bay where the first principal component (PC 1) accounted for 39\% and the second principal 
321 component (PC 2) accounted for $27 \%$ of the variance. The biomarker concentration data

322 and indices used in this analysis were for the taraxerol, sterols, Paq, n-alkanes and fatty 323 acid distributions.

324 The variability among the samples seems to be controlled mainly by OM source and 325 season, and neither the PCs properly define these variables independently. However, PC1 326 seems to more strongly control the special variables separating the POM samples into two 327 groups, namely near-shore (empty diamonds) and offshore areas (filled diamonds) with the 328 exception of samples W1-8 and D2-8. In contrast, PC2 seems to control the seasonal 329 component and roughly separates the D and W series along its axis (with some exceptions).

330 However, analyzing the sample clusters in more detail, one can observe that the W1 331 samples are clearly distinct from W2 samples, except for samples from site 11 which both 332 fall in the W1 cluster. Even sample W1-8 falls into the W1 cluster with a high positive 333 correlation with $\mathrm{PC} 1$ although station 8 is assumed to contain high relative contributions

334 from terrestrial sources. The main difference between the W1 and W2 sampling is that 335 rainfall for the W1 season was about twice that for the W2 season. The average daily 336 precipitation at the Flamingo Ranger Station close to Florida Bay was $0.81 \mathrm{~mm}$ during 337 October 2003 (W1) and 0.39mm during October 2004 (W2); (see http://fcelter.fiu.edu). 338 Based on this, it seems that higher rainfall resulted in increased planktonic/seagrass primary 339 productivity probably due to atmospheric phosphorus inputs into this highly P-limited 340 environment (Sutula, Perez, Reyes, Childers, Davis, \& Day et al., 2003). This result also 341 suggests that potential seasonal variations in POC composition are not primarily driven by 342 hydrology (POM transport) but by primary productivity. Samples W1-11 and W2-11 were 
343 co-located in the PCA plot since this site experiences active P-exchange with waters from

344 the Gulf of Mexico and as such is less sensitive to atmospheric P-inputs.

345 With regards to the D samples, the drier D1 season compared to D2 (0.04mm during

346 March 2004 (D1) and 0.22mm during April 2005 (D2)) was more controlled by hydrology

347 (POM transport from terrestrial environments) compared to D2. And a consistent shift from

348 more terrestrial (negative correlation with PC1) to more marine (positive correlation with

349 PC1) was observed for the nearshore sites (7, 8 and 9), but as expected not for sites 10 and

350 11. These data again suggest that POM in Florida Bay is primarily derived from marine

351 (planktonic/seagrass) OM where primary productivity during the wet season is an important

352 ecological driver. In contrast, the dry season exerts a stronger terrestrial OM influence on

353 the nearshore sites, probably as a result of a relative increase in terrestrial (mangrove) OM

354 transport in comparison with marine biomass primary productivity.

\section{Summary}

Autochthonous/marine sources were the principal contributors to POM in Florida

358 Bay, while allochthonous/terrestrial OM, although minor, played a more important role 359 mostly in the NE, nearshore sites and during the dry season. Multi-biomarker proxies 360 indicated a shift in OM sources along the NE to SW transect from mangrove influenced to 361 plankton/seagrass dominated marine OM inputs. The higher relative abundance of 362 terrestrially derived POM during the dry season relative to the wet season is most likely an 363 indirect consequence of the seasonal primary productivity changes in the Bay.

364 Higher percentages of mono- and poly-unsaturated fatty acids and lower proportions 365 of branched fatty acids in the POM samples relative to surface sediments reflect a 


\section{ACCEPTED MANUSCRIPT}

366 preferential degradation of unsaturated compounds during sedimentation and active

367 microbial reworking at the water-sediment interface.

368 PCA analyses classified the POM samples into two groups according to PC1,

369 namely a nearshore and a more marine influenced group, while PC2 separated the POM

370 samples according to seasonality (hydrology/primary productivity). This study is the first to

371 report seasonal variations in suspended POM compositions in Florida Bay.

372

373 Acknowledgements

374 The authors thank Dr. N. Maie for assistance with sample collection. We also thank

375 the B.R.T. Simoneit and two anonymous reviewers for their helpful comments. This

376 research was supported by the National Science Foundation through the FCE-LTER (DEB-

377 9910514) and the Division of Earth Sciences Geology and Paleontology Program

378 (\#0345812). Y.X. thanks FIU for a presidential fellowship during his Ph. D. study. This is

379 SERC contribution 342. 


\section{References}

382

383

384

385

386

387

388

389

390

391

392

393

394

395

396

397

398

399

400

401

402

403

404

405

406

407

408

409

410

411

412

413

414

415

416

417

418

419

420

421

422

Bianchi, T.S., Mitra, S., \& McKee, B.A. (2002). Sources of terrestrially-derived organic carbon in lower Mississippi River and Louisiana shelf sediments: implications for differential sedimentation and transport at the coastal margin. Marine Chemistry, 77, 211-223.

Brassell, S.C., Eglinton, G., \& Maxwell, J.R. (1983). The geochemistry of terpenoids and steroids. Biochemical Society Transactions, 11, 575-586.

Budge, S.M., \& Parrish, C.C. (1998). Lipid biogeochemistry of plankton, settling matter and sediments in Trinity Bay, Newfoundland. II. Fatty acids. Organic Geochemistry, 29, 1547-1559.

Campbell, S.J., \& Miller, C.J. (2002). Shoot and abundance characteristics of the seagrass Heterozostera tasmanica in Westernport estuary (south-eastern Australia). Aquatic Botany, 73, 33-46.

Canuel, E.A., Cloern, J.E., Ringelberg, D.B., Guckert, J.B., \& Rau, G.H. (1995). Molecular and isotopic tracers used to examine sources of organic matter and its incorporation into the food webs of San Francisco Bay. Limnology and Oceanography, 40, 67-81.

Corbett, D.R., Chanton, J., Burnett, W., Dillon, K., Rutkowski, C., \& Fourqurean, J.W. (1999). Patterns of groundwater discharge into Florida Bay. Limnology and Oceanography, 44, 1045-1055.

Cranwell, P.A., Eglinton, G., \& Robinson, N. (1987). Lipids of aquatic organisms as potential contributors to lacustrine sediment - II. Organic Geochemistry, 11, 513527.

de Leeuw, J.W., Rijpstra, W.I.C., Schenck, P.A., \& Volkman, J.K. (1983). Free, esterified and residual bound sterols in Black Sea Unit I sediments. Geochimica et Cosmochimica Acta, 47, 455-465.

Eadie, B.J., Chambers, R.L., Gardner, W.S., \& Bell, G.E. (1984). Sediment trap studies in Lake Michigan: resuspension and chemical fluxes in the southern basin. Journal of Great Lakes Research, 10, 307-321.

Eglinton, G., \& Hamilton, R.J. (1967). Leaf epicuticular waxes. Science, 156, 1322-1335.

Ficken, K.J., Li, B., Swain, D.L., \& Eglinton, G. (2000). An $n$-alkane proxy for the sedimentary input of submerged/floating freshwater aquatic macrophytes. Organic Geochemistry, 31, 745-749.

Fourqurean, J.W., \& Robbins, M.B. (1999). Florida Bay: a history of recent ecological changes. Estuaries, 22, 345-357.

Gogou, A., \& Stephanou, E.G. (2004). Marine organic geochemistry of the Eastern Mediterranean: 2. Polar biomarkers in Cretan Sea surficial sediments. Marine Chemistry, 85, 1-25.

Hernandez, M.E., Mead, R., Peralba, M.C., \& Jaffé, R. (2001). Origin and transport of $n$ alkan-2-ones in a subtropical estuary: potential biomarkers for seagrass-derived organic matter. Organic Geochemistry, 32, 21-32.

Huang, W., \& Meinschein, W.G. (1976). Sterols as source indicators of organic materials in sediments. Geochimica et Cosmochimica Acta, 40, 323-330. 
Huang, W.-Y., \& Meinschein, W.G. (1978). Sterols in sediments from Baffin Bay, Texas. Geochimica et Cosmochimica Acta, 42, 1391-1396.

Jaffé, R., Boyer, J.N., Lu, X., Maie, N., Yang, C., Scully, N.M., \& Mock, S. (2004). Source characterization of dissolved organic matter in a subtropical mangrovedominated estuary by fluorescence analysis. Marine Chemistry, 84, 195-210.

Jaffé, R., Cabrera, A., Hajje, N., \& Carvajal-Chitty, H. (1996). Organic biogeochemistry of a hypereutrophic tropical, freshwater lake - Part 1: particle associated and dissolved lipids. Organic Geochemistry, 25, 227-240.

Jaffé, R., Mead, R., Hernandez, M.E., Peralba, M.C., \& DiGuida, O.A. (2001). Origin and transport of sedimentary organic matter in two subtropical estuaries: a comparative, biomarker-based study. Organic Geochemistry, 32, 507-526.

Jiang, S., O'Leary, T., Volkman, J.K., Zhang, H., Jia, R., Yu, S., Wang, Y., Luan, Z., Sun, Z., \& Jiang, R. (1994). Origins and simulated thermal alteration of sterols and ketoalcohols in deep-sea marine sediments of the Okinawa Trough. Organic Geochemistry, 21, 415-422.

Kenig, F., Sinninghe Damsté, J.S., Kock-van Dalen, A.C., Rijpstra, W.I.C., Huc, A.Y., \& de Leeuw, J.W. (1995). Occurrence and origin of mono-, di-, and trimethylalkanes in modern and Holocene cyanobacterial mats from Abu Dhabi, United Arab Emirates. Geochimica et Cosmochimica Acta, 59, 2999-3015.

Mead, R., Xu, Y., Chong, J., \& Jaffé, R. (2005). Sediment and soil organic matter source assessment as revealed by the molecular distribution and carbon isotopic composition of n-alkanes. Organic Geochemistry, 36, 363-370.

McCallister, S.L., Bauer, J.E., Ducklow, H.W., \& Canuel, E.A. (2006). Sources of estuarine dissolved and particulate organic matter: A multi-tracer approach. Organic Geochemistry, 37, 454-468.

Maie, N., Boyer, J.N., Yang, C., \& Jaffé, R. (2006). Spatial, geomorphologic, and seasonal variability in CDOM in estuaries of Florida Coastal Everglades. Hydrobiologia, in press.

Meyers, P.A. (2003). Applications of organic geochemistry to paleolimnological reconstructions: a summary of examples from the Laurentian Great Lakes. Organic Geochemistry, 34, 261-289.

Mudge, S.M., East, J.A., Bebianno, M.J., \& Barreira, L.A. (1998). Fatty acids in the Ria Formosa Lagoon, Portugal. Organic Geochemistry, 29, 963-977.

Neto, R.R., Mead, R.N., Louda, J.W., \& Jaffé, R. (2006). Organic biogeochemistry of detrital flocculent material (Floc) in a subtropical, coastal wetland. Biogeochemistry, 77, 283-304.

Paula, J., Fidalgo Ecosta, P., Martins, A., \& Gove, D. (2001). Patterns of abundance of seagrasses and associated infaunal communities at Inhaca Island, Mozambique. Estuarine, Coastal and Shelf Science, 53, 307-318.

Philips, E.J., Lynch, T.C., \& Badylak, S. (1995). Chlorophyll a, tripton, color, and light availability in a shallow tropical inner-shelf lagoon, Florida Bay, USA. Marine Ecology Progress Series, 127, 223-234.

Prartono, T., \& Wolff, G.A. (1998). Organic geochemistry of lacustrine sediments: a record of the changing trophic status of Rostherne Mere, U.K. Organic Geochemistry, 28, 729-747. 
Ramos, C.S., Parrish, C.C., Quibuyen, T.A.O., \& Abrajano, T.A. (2003). Molecular and carbon isotopic variations in lipids in rapidly settling particles during a spring phytoplankton bloom. Organic Geochemistry, 34, 195-207.

Robinson, N., Cranwell, P.A., Finlay, B.J., \& Eglinton, G. (1984). Lipids of aquatic organisms as potential contributors to lacustrine sediments. Organic Geochemistry, 6, 143-152.

Saliot, A., Mejanelle, L., Scribe, P., Fillaux, J., Pepe, C., Jabaud, A., \& Dagaut, J. (2001). Particulate organic carbon, sterols, fatty acids and pigments in the Amazon River system. Biogeochemistry, 53, 79-103.

Sever, J., \& Parker, P.L. (1969). Fatty alcohols (normal and isoprenoid) in sediments. Science, 164, 1052-1054.

Sinninghe Damsté, J.S., Muyzer, G., Abbas, B., Rampen, S.W., Massé, G., Allard, W.G., Belt, S.T., Robert, J.-M., Rowland, S.J., Moldowan, J.M., Barbanti, S.M., Fago, F.J., Denisevich, P., Dahl, J., Trinidade, L.A.F., \& Schouten, S. (2004). The rise of rhizosolenid diatoms. Science, 304, 584-587.

Sutula, M.A., Perez, B.C., Reyes, E., Childers, D.L., Davis, S., Day, J., John W., Rudnick, D., Sklar, F. (2003). Factors affecting spatial and temporal variability in material exchange between the Southern Everglades wetlands and Florida Bay (USA). Estuarine, Coastal and Shelf Science, 57, 757-781.

ten Haven, H.L., \& Rullkötter, J. (1988). The diagenetic fate of taraxer-14-ene and oleanene isomers. Geochimica et Cosmochimica Acta, 52, 2543-2548.

Versteegh, G.J.M., Schefuß, E., Dupont, L., Marret, F., Sinninghe Damsté, J.S., \& Jansen, J.H.F. (2004). Taraxerol and Rhizophora pollen as proxies for tracking past mangrove ecosystems. Geochimica et Cosmochimica Acta, 68, 411-422.

Volkman, J.K. (1986). A review of sterol markers for marine and terrigenous organic matter. Organic Geochemistry, 9, 83-99.

Volkman, J.K., Barrett, S.M., Blackburn, S.I., Mansour, M.P., Sikes, E.L., \& Gelin, F. (1998). Microalgal biomarkers: A review of recent research developments. Organic Geochemistry, 29, 1163-1179.

Volkman, J.K., Barrett, S.M., \& Dunstan, G.A. (1994). $\mathrm{C}_{25}$ and $\mathrm{C}_{30}$ highly branched isoprenoid alkenes in laboratory cultures of two marine diatoms. Organic Geochemistry, 21, 407-414.

Volkman, J.K., Rohjans, D., Rullkötter, J., Scholz-Bottcher, B.M., \& Liebezeit, G. (2000). Sources and diagenesis of organic matter in tidal flat sediments from the German Wadden Sea. Continental Shelf Research, 20, 1139-1158.

Wakeham, S.G., \& Beier, J.A. (1991). Fatty acid and sterol biomarkers as indicators of particulate matter source and alteration processes in the Black Sea. Deep-Sea Research, 38, S943-S968.

Wakeham, S.G., \& Lee, C. (1989). Organic geochemistry of particulate matter in the ocean: The role of particles in oceanic sedimentary cycles. Organic Geochemistry, 14, 8396.

Xu, Y., Jaffé, R., Wachnicka, A., \& Gaiser, E.E. (2006a). Occurrence of $\mathrm{C}_{25}$ highly branched isoprenoids (HBIs) in Florida Bay: paleoenvironmental indicators of diatom-derived organic matter inputs. Organic Geochemistry, 37, 847-859. 
512 Xu, Y., Mead, R., \& Jaffé, R. (2006b). A molecular marker based assessment of

513 sedimentary organic matter sources and distributions in Florida Bay. Hydrobiologia, $514 \quad 569,179-192$.

515 Zieman, J.C., Fourqurean, J.W., \& Iverson, R.L. (1989). Distribution, abundance and

516

517 productivity of seagrasses and macroalgae in Florida Bay. Bulletin of Marine

518 Science, 44, 292-311. 
519

520

521

522

523

524

525

527

528

529

530

531

532

533

534

535

536

537

538

539

540

541

542

543

544

545

546

547

548

549

550

\section{Figure and table captions:}

Fig. 1: Geographic locations of particulate organic matter sampling sites in Florida Bay

Fig. 2: Representative GC/MS chromatograms of (A) n-alkanes, (B) fatty acids, (C) $n$ alcohols and (D) sterols in particulate organic matter from Florida Bay

Fig. 3: The $P a q$ distributions in particulate organic matter from Florida Bay.

Paq $=\left(\mathrm{C}_{23}+\mathrm{C}_{25}\right) /\left(\mathrm{C}_{23}+\mathrm{C}_{25}+\mathrm{C}_{29}+\mathrm{C}_{31}\right) n$-alkanes

Fig. 4: Relative abundance of $\mathrm{C}_{26}, \mathrm{C}_{27}, \mathrm{C}_{28}, \mathrm{C}_{29}$ and $\mathrm{C}_{30}$ sterols in particulate organic matter from Florida Bay

Fig. 5: Biomarker-based score plot of the first two principal components (PC-1 and PC-2) for suspended particles from Florida Bay

Table 1: Concentration of $n$-alkanes, $n$-alkanols, triterpenoids, fatty acids, HBIs and sterols in Florida Bay suspended particles during dry season (D) and wet season (W)

Table 2: Comparison of biomarker proxies between POM and surface sediments in Florida Bay 


\section{ACCEPTED MANUSCRIPT}

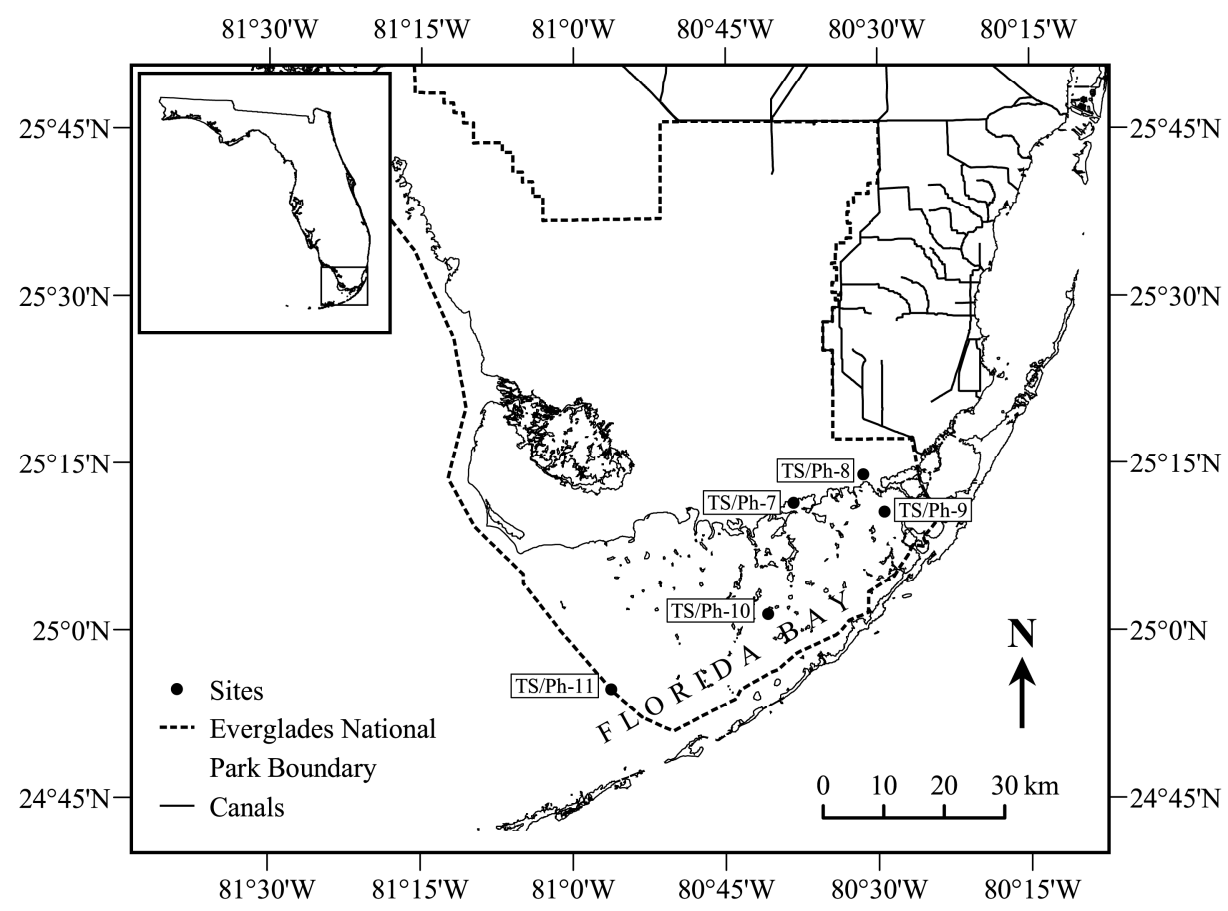




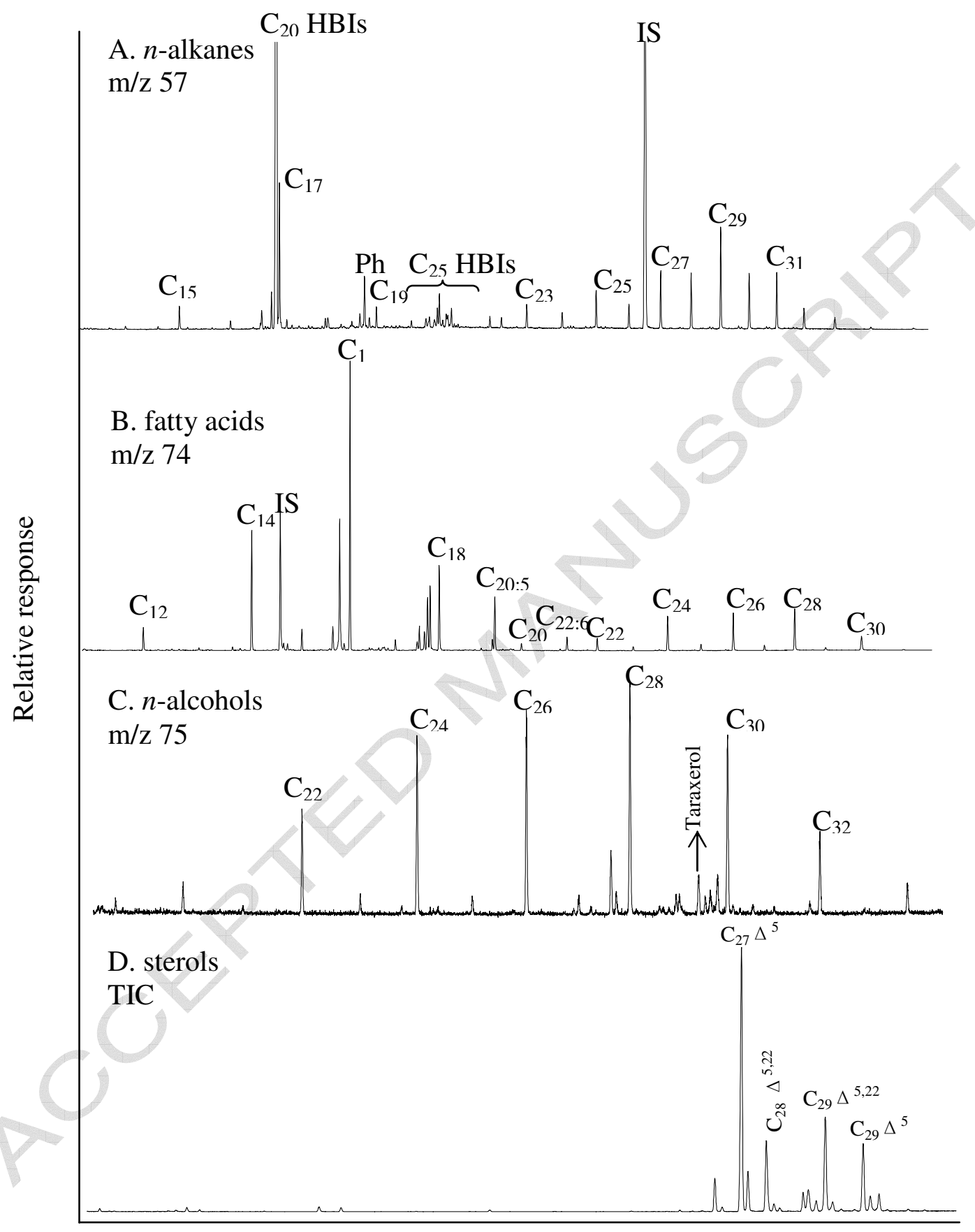

555 Fig. 2 


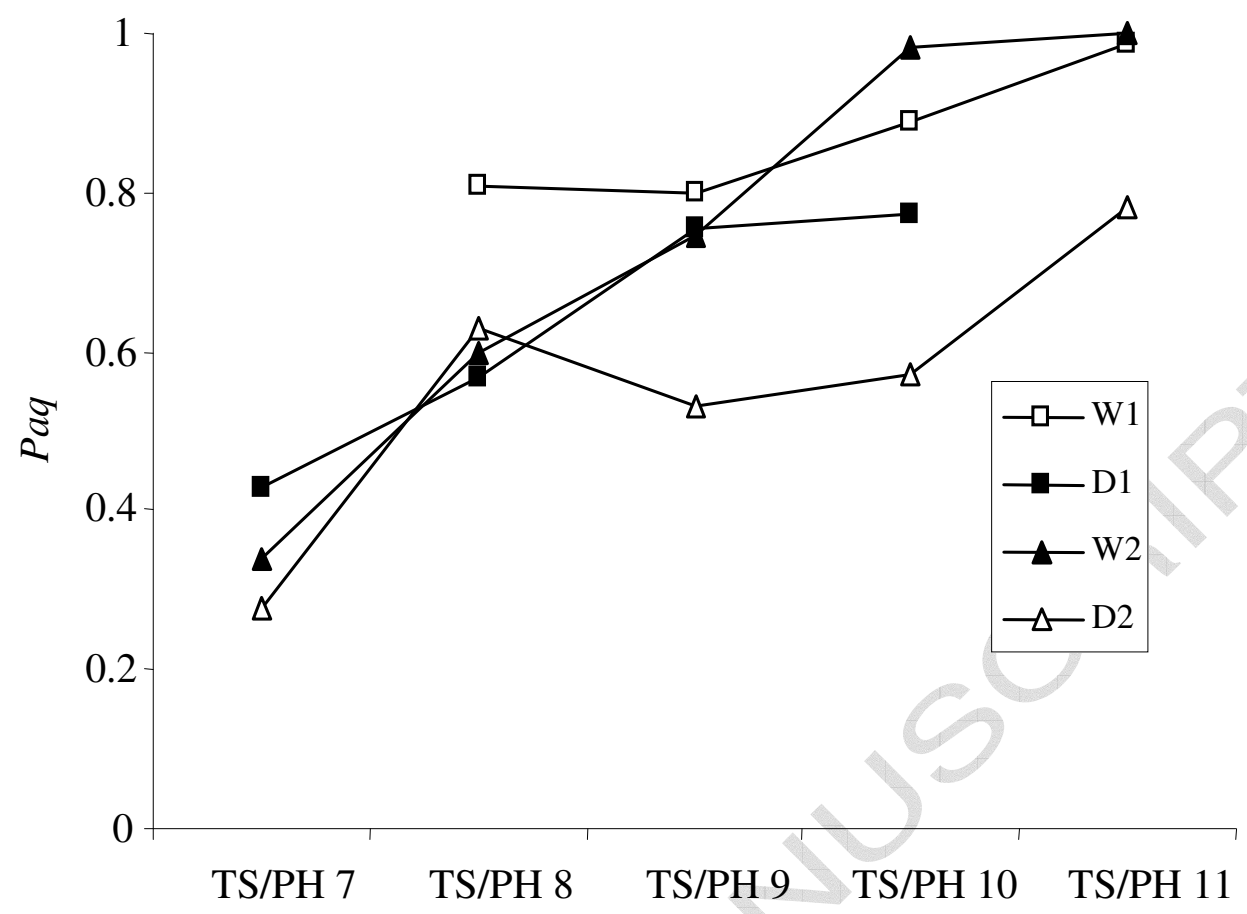

Fig. 3

556

557

558

559

560

561

562

563

564

565

566 


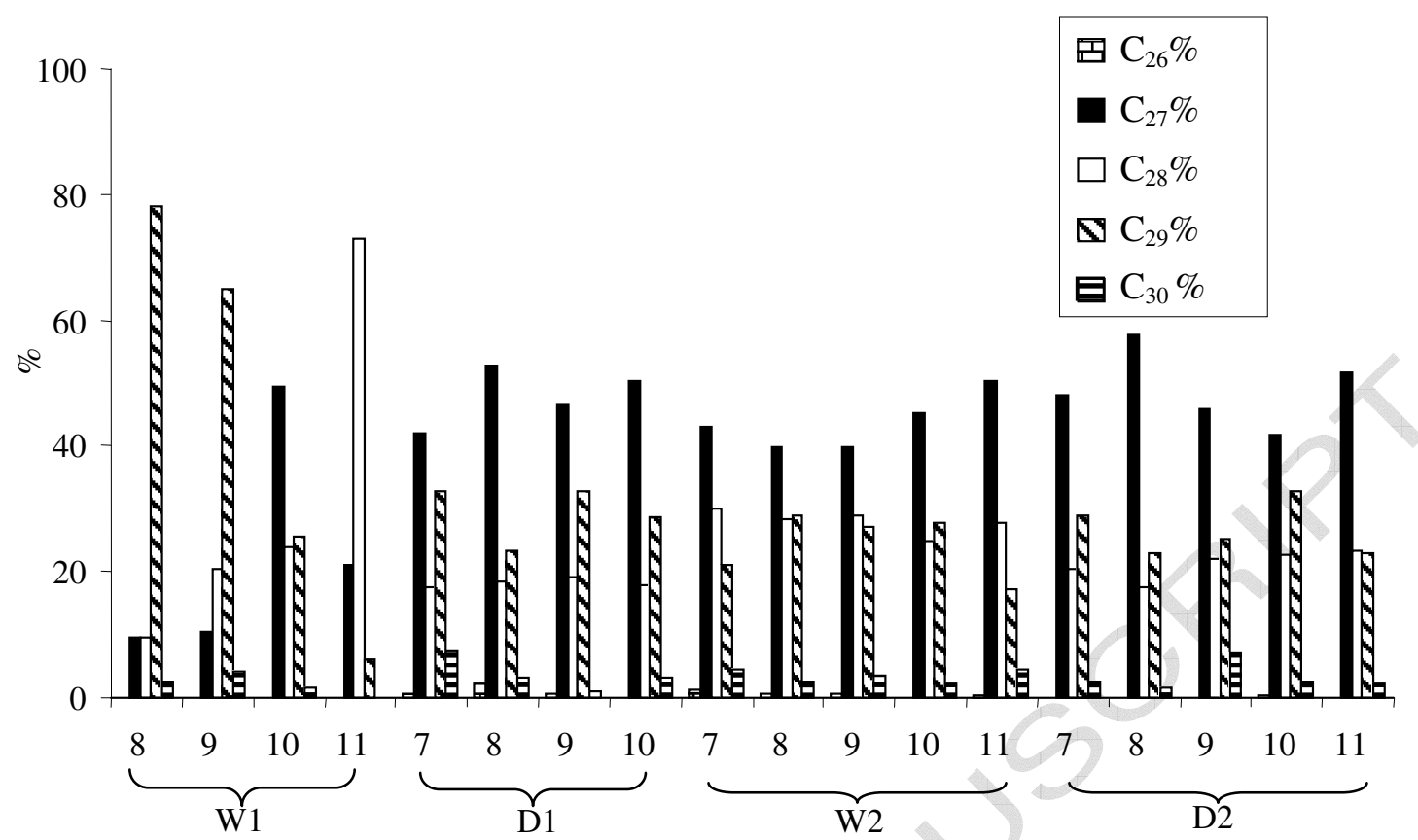

Fig. 4 


\section{ACCEPTED MANUSCRIPT}

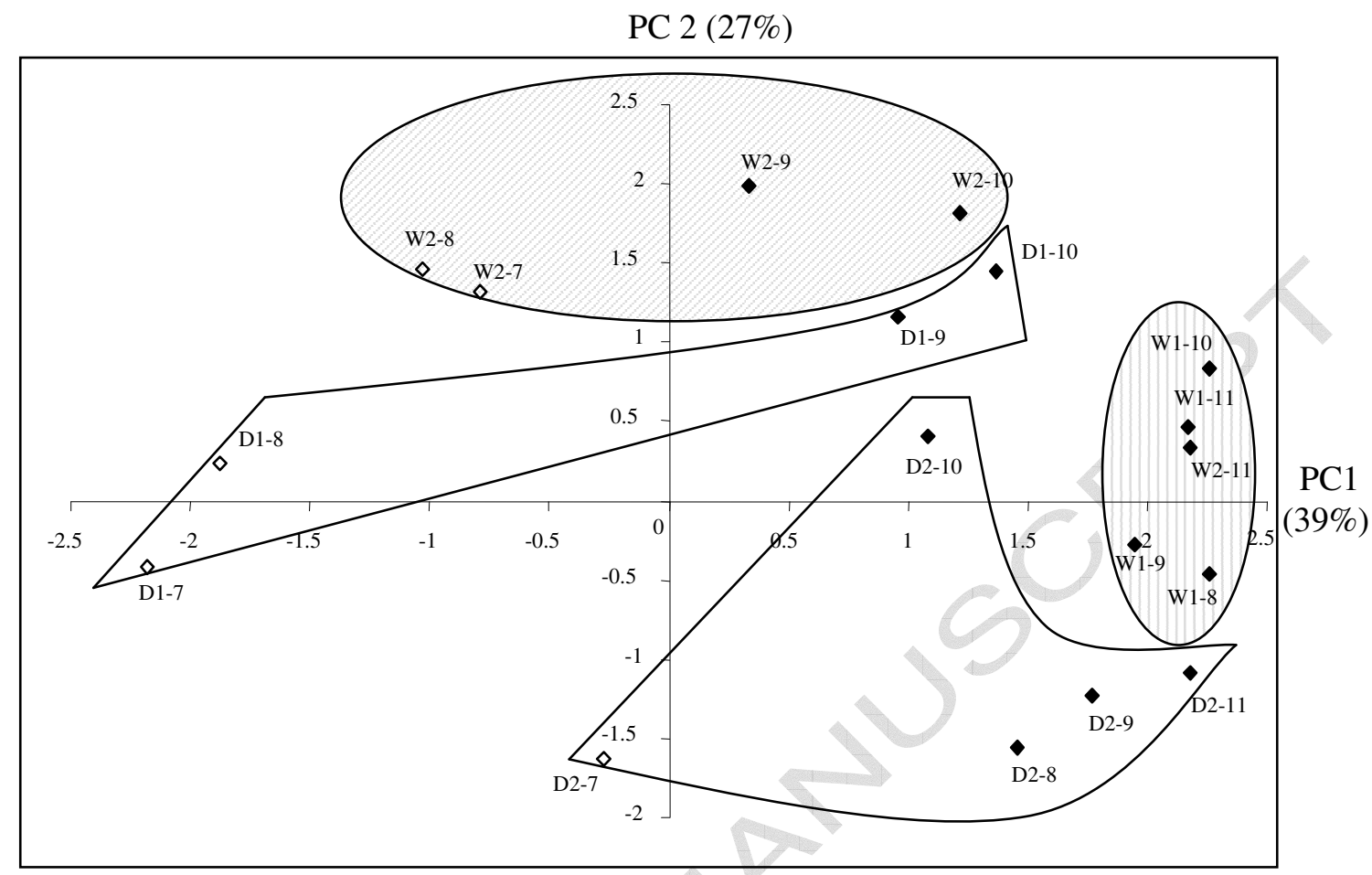

Fig. 5

580 
Table 1 Concentration of $n$-alkanes, $n$-alkanols, triterpenoids, fatty acids, HBIs and sterols in Florida Bay suspended particulates during dry season (D) and wet season (W)

\begin{tabular}{|c|c|c|c|c|c|c|c|c|c|c|c|c|c|c|c|c|c|c|}
\hline & \multicolumn{4}{|c|}{ W1 } & \multicolumn{4}{|c|}{ D1 } & \multicolumn{5}{|c|}{ W2 } & \multicolumn{5}{|c|}{ D2 } \\
\hline & 8 & 9 & 10 & 11 & 7 & 8 & 9 & 10 & 7 & 8 & 9 & 10 & 11 & 7 & 8 & 9 & 10 & 11 \\
\hline \multicolumn{19}{|l|}{$\overline{n \text {-Alkanes }}$} \\
\hline Total & 119 & 338 & 349 & 281 & 316 & 266 & 37 & 95 & 43 & 163 & 76 & 75 & 38 & 128 & 95 & 73.7 & 214 & 60 \\
\hline $\mathrm{C}_{29}+\mathrm{C}_{31}$ & 1.8 & 3 & 1 & 1 & 41 & 12 & 1 & 3 & 4 & 10 & 2 & 0.2 & 0 & 29 & 8 & 5 & 6 & 4 \\
\hline$P a q$ & 0.8 & 0.8 & 0.9 & 1.0 & 0.4 & 0.6 & 0.8 & 0.8 & 0.3 & 0.6 & 0.7 & 1.0 & 1.0 & 0.3 & 0.6 & 0.5 & 0.6 & 0.8 \\
\hline $\mathrm{Cmax}$ & $\mathrm{C}_{17}$ & $\mathrm{C}_{17}$ & $\mathrm{C}_{15}$ & $\mathrm{C}_{23}$ & $\mathrm{C}_{15}$ & $\mathrm{C}_{15}$ & $\mathrm{C}_{15}$ & $\mathrm{C}_{15}$ & $\mathrm{C}_{15}$ & $\mathrm{C}_{15}$ & $\mathrm{C}_{15}$ & $\mathrm{C}_{21}$ & $\mathrm{C}_{15}$ & $\mathrm{C}_{17}$ & $\mathrm{C}_{17}$ & $\mathrm{C}_{15}$ & $\mathrm{C}_{15}$ & $\mathrm{C}_{15}$ \\
\hline Short & 96 & 293 & 326 & 140 & 195 & 212 & 22 & 63 & 33 & 103 & 51 & 50 & 21 & 34 & 45 & 50 & 177 & 23 \\
\hline Long & 23 & 46 & 23 & 141 & 121 & 55 & 15 & 33 & 10 & 60 & 26 & 54 & 17 & 86 & 50 & 23 & 36 & 35 \\
\hline Long/short & 4.1 & 6.3 & 14 & 1.0 & 1.6 & 3.8 & 1.5 & 1.9 & 3.2 & 1.7 & 2.0 & 0.9 & 1.2 & 0.4 & 0.9 & 2.2 & 5 & 0.7 \\
\hline ACL & 18.5 & 17.9 & 16.5 & 20.6 & 20.1 & 17.5 & 19.7 & 20.6 & 18.2 & 19.6 & 19.4 & 20.5 & 19.4 & 25 & 21.8 & 19.3 & 17.6 & 21.5 \\
\hline CPI & 7.1 & 3.4 & 5.4 & 1.6 & 7.8 & 10.9 & 2.1 & 1.9 & 7.1 & 3.0 & 1.6 & 1.9 & 2.2 & 2.4 & 1.4 & 5.1 & 11.3 & 3.8 \\
\hline$\%\left(\mathrm{C}_{15}+\mathrm{C}_{17}\right)$ & 69 & 61 & 76 & 11 & 57 & 75 & 32 & 31 & 68 & 41 & 33 & 12 & 31 & 24 & 15 & 63 & 81 & 33 \\
\hline$\%\left(\mathrm{C}_{29}+\mathrm{C}_{31}\right)$ & 1.5 & 0.9 & 0.3 & 0.3 & 13 & 4.7 & 3.2 & 2.7 & 8.1 & 6.0 & 2.8 & 0.2 & 0.0 & 24 & 8.8 & 6.2 & 2.7 & 6.8 \\
\hline \multicolumn{19}{|l|}{ n-Alkanols } \\
\hline Total & 16 & 59 & 48 & 29 & 1220 & 406 & 41 & 63 & 122 & 218 & 80 & 203 & 155 & 143 & 130 & 41 & 177 & 30 \\
\hline $\mathrm{Cmax}$ & $\mathrm{C}_{14}$ & $\mathrm{C}_{12}$ & $\mathrm{C}_{18}$ & $\mathrm{C}_{12}$ & $\mathrm{C}_{30}$ & $\mathrm{C}_{28}$ & $\mathrm{C}_{18}$ & $\mathrm{C}_{18}$ & $\mathrm{C}_{18}$ & $\mathrm{C}_{12}$ & $\mathrm{C}_{12}$ & $\mathrm{C}_{12}$ & $\mathrm{C}_{12}$ & $\mathrm{C}_{28}$ & $\mathrm{C}_{14}$ & $\mathrm{C}_{18}$ & $\mathrm{C}_{18}$ & $\mathrm{C}_{18}$ \\
\hline $\begin{array}{r}\text { Long/short } \\
\text { Triterpenoids }\end{array}$ & 0.3 & 0.3 & 0.0 & 0.0 & & 7.8 & 1.5 & 0.2 & 0.0 & 1.4 & 0.1 & 0.1 & 0.0 & 3.9 & 0.9 & 1.0 & 0.5 & 0.5 \\
\hline Taraxerol & 7 & 19 & 0.0 & 0.0 & 1210 & 181 & 9 & 8.4 & 102 & 30 & 0.0 & 0.0 & 0.0 & 109 & 21 & 2 & 1 & 0.0 \\
\hline$\beta$-amyrin & 0.0 & 9.9 & 0.0 & 0.0 & 518 & 97 & 0.0 & 0.0 & 0.0 & 0.0 & 0.0 & 0.0 & 0.0 & 4 & 5 & 0.0 & 0.0 & 0.0 \\
\hline Germanicol & 0.0 & 0.0 & 0.0 & 0.0 & 131 & 29 & 0.0 & 0.0 & 0.0 & 0.0 & 0.0 & 0.0 & 0.0 & 0.0 & 1.6 & 0.0 & 0.0 & 0.0 \\
\hline Lupeol & 7.0 & 0.0 & 0.0 & 0.0 & 231 & 39 & 0.0 & 0.0 & 18 & 7.0 & 0.0 & 0.0 & 0.0 & 0.0 & 0.0 & 0.0 & 0.0 & 0.0 \\
\hline
\end{tabular}




\section{Table 1 continued}

Fatty acids

\begin{tabular}{|c|c|c|c|c|c|c|c|c|c|c|c|c|c|c|c|c|c|c|}
\hline Total & 153 & 40 & 165 & 601 & 2580 & 1063 & 1230 & 1980 & 598 & 214 & 270 & 535 & 454 & \multicolumn{2}{|c|}{$1370 \quad 1824$} & 1800 & 3411 & 1130 \\
\hline Short & 149 & 40 & 162 & 587 & 2000 & 832 & 1180 & 1800 & 543 & 161 & 246 & 495 & 436 & 662 & 752 & 869 & 1140 & 577 \\
\hline Long & 3.7 & 0.0 & 3.4 & 14 & 577 & 231 & 44 & 184 & 55 & 53 & 24 & 41 & 18 & 202 & 185 & 174 & 223 & 72 \\
\hline Short/long & 39.8 & nd & 47.4 & 41.1 & 3.5 & 3.6 & 26.7 & 9.7 & 10.0 & 3.0 & 10.5 & 12.2 & 23.9 & 3.3 & 4.1 & 5.0 & 5.1 & 8.0 \\
\hline MUFAs (\%) & 26 & 21 & 27 & 16 & 20 & 18 & 23 & 23 & 15 & 7.0 & 11 & 17 & 20 & 11 & 16 & 18 & 23 & 24 \\
\hline PUFAs (\%) & 10 & 0.9 & 7.5 & 11 & 6.5 & 8.6 & 9.6 & 9.0 & 3.3 & 0.2 & 0.9 & 1.5 & 1.2 & 22 & 21 & 20 & 35 & 16 \\
\hline Br-FAs (\%) & 3.5 & 2.3 & 1.7 & 1.2 & 2.1 & 1.2 & 1.1 & 1.5 & 0.8 & 0.6 & 0.7 & 2.0 & 1.7 & 3.9 & 3.1 & 3.5 & 2.3 & 3.0 \\
\hline C16:1/C16:0 & 0.6 & 0.3 & 0.3 & 0.8 & 0.3 & 0.3 & 0.4 & 0.5 & 0.2 & 0.1 & 0.1 & 0.2 & 0.2 & 0.5 & 0.4 & 0.5 & 0.7 & 0.3 \\
\hline $\mathrm{C} 16 / \mathrm{C} 18$ & 2.1 & 3.2 & 2.0 & 2.8 & 1.6 & 1.7 & 1.9 & 1.7 & 2.2 & 2.0 & 1.7 & 2.1 & 2.3 & 2.0 & 1.9 & 1.7 & 0.9 & 1.0 \\
\hline $\mathrm{A} / \mathrm{B}$ & 8.7 & nd & 3.1 & 0.6 & 3.9 & 3.2 & 5.5 & 7.0 & 4.1 & nd & nd & nd & nd & 4.1 & 5.4 & 11.9 & 2.8 & 1.3 \\
\hline HBIs & & & & & & & & & 10 & & & & & & & & & \\
\hline $\mathrm{C}_{20}$ HBIs & 154 & 282 & 148 & 7.1 & 404 & 191 & 58 & 133 & 40 & 52 & 77 & 17 & 1.1 & 410 & 71 & 145 & 433 & 4.3 \\
\hline $\mathrm{C}_{25}$ HBIs & 13 & 41 & 91 & 0.0 & 35 & 22 & 14 & 56 & 3.0 & 16 & 24 & 0.0 & 0.0 & 56 & 33 & 9.8 & 100 & 0.0 \\
\hline $\mathrm{C}_{30} \mathrm{HBIs}$ & nd & nd & nd & nd & nd & nd & nd & nd & nd & nd & nd & nd & nd & 10.3 & nd & nd & nd & nd \\
\hline \multicolumn{19}{|l|}{ Sterols } \\
\hline Total & 180 & 91 & 526 & 800 & 3040 & 2290 & 1137 & 1090 & 1380 & 1460 & 1040 & 1180 & 161 & 596 & 451 & 430 & 1500 & 309 \\
\hline
\end{tabular}

All concentrations are expressed in ng/L. Cmax: the maximum compounds in homologues.

Short: total concentrations of short-chain homologues $\left(\leq \mathrm{C}_{20}\right)$. Long: total concentrations of long-chain homologues $\left(>\mathrm{C}_{20}\right)$. ACL $=$ average chain length of the homologues. $\mathrm{CPI}=$ carbon preference index. MUFAs $=$ mono-unsaturated fatty acids. PUFAs $=$ poly-

unsaturated fatty acids. Br-FAs- $=$ branched- $\mathrm{C}_{15}+\mathrm{C}_{17}$ fatty acids indicative of bacterial contributions. $\mathrm{A} / \mathrm{B}=$ the ratio of $\mathrm{C}_{20: 5}$ over $\mathrm{C}_{22: 6}$ fatty acids. $\mathrm{nd}=$ not detected 


\section{ACCEPTED MANUSCRIPT}

Table 2

\begin{tabular}{llllllllllll}
\hline & \multicolumn{3}{c}{$\mathrm{TS} / \mathrm{Ph} 7$} & \multicolumn{2}{c}{$\mathrm{TS} / \mathrm{Ph} 8$} & \multicolumn{2}{c}{$\mathrm{TS} / \mathrm{Ph} 9$} & \multicolumn{2}{c}{$\mathrm{TS} / \mathrm{Ph} 10$} & \multicolumn{2}{c}{$\mathrm{TS} / \mathrm{Ph} 11$} \\
\hline$n$-alkane & $\mathrm{POM}$ & $\mathrm{Sed}$. & $\mathrm{POM}$ & $\mathrm{Sed}$. & $\mathrm{POM}$ & $\mathrm{Sed}$ & $\mathrm{POM}$ & $\mathrm{Sed}$ & $\mathrm{POM}$ & $\mathrm{Sed}$. \\
Paq & 0.33 & 0.44 & 0.65 & na & 0.7 & 0.53 & 0.83 & 0.63 & 0.94 & 0.83 \\
Cmax & $\mathrm{C}_{15}$ & $\mathrm{C}_{29}$ & $\mathrm{C}_{15}$ & na & $\mathrm{C}_{15}$ & $\mathrm{C}_{25}$ & $\mathrm{C}_{15}$ & $\mathrm{C}_{25}$ & $\mathrm{C}_{23}$ & $\mathrm{C}_{25}$ \\
$\mathrm{ACL}$ & 21.1 & 26.6 & 19.4 & na & 19.1 & 25.7 & 18.8 & 24.5 & 20.5 & 21.4 \\
$\%\left(\mathrm{C}_{15}+\mathrm{C}_{17}\right)$ & 50 & 2.6 & 67 & na & 47 & 7.4 & 50 & 9.7 & 25 & 13 \\
$\%\left(\mathrm{C}_{29}+\mathrm{C}_{31}\right)$ & 16 & 29 & 5.3 & na & 3.3 & 23 & 1.5 & 10 & 2.4 & 4.6 \\
Fatty acids & & & & & & & & & & \\
PUFA\% & 11 & 0.7 & 10 & na & 8 & 4.4 & 13 & 8.2 & 9.2 & 13 \\
MUFA\% & 15 & 4.9 & 17 & na & 18 & 6.4 & 23 & 11 & 20 & 37 \\
BrFA\% & 2.3 & 7.3 & 2.1 & na & 1.9 & 5.2 & 1.9 & 8 & 2 & 15 \\
Sterol & & & & & & & & & & \\
$\mathrm{C}_{27} \%$ & 44 & 19 & 40 & na & 36 & 37 & 47 & 38 & 41 & 42 \\
$\mathrm{C}_{28} \%$ & 23 & 17 & 18 & na & 23 & 17 & 22 & 19 & 41 & 22 \\
$\mathrm{C}_{29} \%$ & 28 & 64 & 38 & na & 38 & 46 & 29 & 43 & 15 & 36 \\
$n$-alkanol & & & & & & & & & & \\
Long/short & 4.6 & 10 & 2.6 & na & 0.7 & 50 & 0.2 & 6.3 & 0.1 & 1.8 \\
\hline na = not analyzed & & & & & & & & &
\end{tabular}

*The data on sediments are from Xu et al., 2006b while data on POM are the average values from this study. 